\title{
EDITORIAL
}

\section{Pain in women}

\author{
Anita M Unruh PhD MSW OT(c) RegNS
}

$\mathrm{T}$ his issue of Pain Research $\mathcal{E}$ Management recognizes the International Association for the Study of Pain (IASP) Global Year of Pain in Women.

The artwork on the cover of this issue was submitted by Heather Davulcu. Heather's migraines started when she was 28 years old. They were severe, debilitating and often daily in their occurrence. The side effects of her medications were sometimes as problematic as the migraines themselves and none were effective in adequately managing the pain. She had many consultations with medical specialists and frequent visits to emergency clinics; at times she was hospitalized for the pain. The absence of migraines during her pregnancies and the fluctuations in the migraines due to her menstrual cycle convinced Heather that her hormones played a significant role. Eventually, she convinced her obstetrician/gynecologist that, despite her young age, she needed a hysterectomy. Following three months of medically induced menopause, Heather had a hysterectomy on May 23, 2006, and has been migraine-free ever since. Heather said of her artwork:

"During the times when it was most severe I felt completely detached from my family and from life in general. I sought to relay these emotions but the only way I could do so was through art."

Don't Let them Know is a mixed media piece. Heather created this piece out of her worry about the effect of her pain on her daughters. She used images and words from a variety of sources, even her medication packages. Heather tried to keep her suffering from her children. Her youngest daughter did not really understand, but her older daughter is illustrated as reaching up to see what her mother is withholding. Looking at this picture, I saw questions embedded in it about identity and the struggle women often experience in trying to create meaning out of living with chronic pain. It reminded me of the comments in the qualitative paper in this issue on the process toward acceptance of pain for women living with arthritis or fibromyalgia (1), a process that is often about loss, grief and reconciliation of the self with the body. Heather submitted her work for this issue because it was important to her to contribute to the IASP campaign Real Women, Real Pain.

Helen Tupper has lived with the chronic pain of failed back surgery and fibromyalgia. She has contributed in so many ways to make pain better understood. Helen is also an artist. For Helen, the heart of painting was the escape from pain into her art. A very significant part of living with chronic pain for Helen has been her work in support programs and advocacy for better pain management. Although she entered this arena reluctantly, she eventually led her local support group, became the president of the North American Chronic Pain Association of Canada (NACPAC) (now the Chronic Pain Association of Canada), planned community workshops on chronic pain for others living with pain, became the first president of the Canadian Pain Coalition (a collaboration she helped to establish along with Celeste Johnston) and sat as a member on the Canadian Pain Society (CPS) executive. Many of these endeavours involved strenuous, pain-aggravating activities because of the inherent travel, leadership and participation in meetings and conferences. Helen persisted, saying: "When I was sidelined by pain I began to think my world was shrinking, but when I became involved with NACPAC, CPS and the Canadian Pain Coalition, I saw that I still had something to offer. I became a nurse to help others. That desire was still there and I could still fulfill it in this way."

Participating in professional meetings was reassuring to Helen. She saw that doctors and other health professionals did care about women (and children and men) with pain, and were actively working toward solutions, a message she took back to consumer groups.

Much has happened in the past 15 years to examine more thoroughly the biological, psychological, social and cultural issues that relate to sex and gender in the overall experience of pain. The initial experimental and epidemiological research provided the platform for the 1997 targeted call from the National Institutes of Health in the United States for research in sex, gender and pain. In 1998, this call led to the National Institutes of Health-sponsored conference on gender and pain. By 2000, there was sufficient research for the first book in this area (2). During the same period, the IASP established a Task Force and then a Special Interest Group on Sex, Gender and Pain. The Special Interest Group has been active in preparing a series of Fact Sheets on specific aspects of pain in this area as part of the Real Women, Real Pain campaign (see www.iasppain.org). At national and international pain conferences, keynote and plenary addresses on sex and gender issues in pain are now common; in this global year, there have again been conferences worldwide that focus on pain in women, and gendercomparative research.

This special issue is an important contribution to the global year activities. The papers include a qualitative study examining the process toward acceptance for women living with arthritis and/or fibromyalgia (1), a review of dyspareunia in postmenopausal women (3), the application of a cognitivebehavioral approach to sexual function for women with chronic pain (4), a review of the pain of vulvodynia and its influence on the lives of women who live with it (5), an exploration of the impact of smoking on pain perception in women (6) and

Correspondence: Dr Anita M Unruh, Faculty of Health Professions, Dalhousie University, 6230 South Street, Halifax, Nova Scotia B3H $3 J 5$.

Telephone 902-494-3829, fax 902-494-5120, e-mail anita.unruh@dal.ca 
an examination of the impact of depression on activity-related pain in women (7). We included two gender-comparative studies exploring the different influences of mothers and fathers on their children's pain experiences $(8,9)$. These papers answer questions and raise many more. They will be a catalyst for further research and add to the growing body of sex- and genderrelated research in the basic, applied and clinical sciences of pain.

ACKNOWLEDGEMENT: Many thanks to those who submitted manuscripts, to reviewers, to Katherine Harman who reviewed one manuscript with which I was in conflict and to Ken Craig for the opportunity to participate as a Guest Editor of this special issue.

\section{REFERENCES}

1. LaChapelle DL, Lavoie S, Boudreau A. The meaning and process of pain acceptance. Perceptions of women living with arthritis and fibromyalgia. Pain Res Manage 2008;13:201-10.

2. Fillingim RB. Sex, Gender, and Pain. Seattle: IASP Press, 2000.

3. Kao A, Binik YM, Kapuscinski A, Khalifé S. Dyspareunia in postmenopausal women: A critical review. Pain Res Manage 2008; 13:243-54.

4. Breton A, Miller CM, Fisher K. Enhancing the sexual function of women living with chronic pain: A cognitive-behavioral treatment group. Pain Res Manage 2008;13:219-24.

5. Cantin-Drouin M, Damant D, Turcotte D. Une recension des écrits concernant la réalité psychoaffective des femmes ayant une vulvodynie : Difficultés rencontrées et stratégies développées. Pain Res Manage 2008;13:255-63.
NOTE: Heather Davulcu and Helen Tupper read this editorial and gave permission for the use of their words, which were communicated to me personally.

$$
\begin{array}{r}
\text { Anita M Unruh, PhD MSW OT(c) RegNS } \\
\text { Guest Editor } \\
\text { Pain Research E Management } \\
\text { Professor, Health and Human Performance, } \\
\text { and Occupational Therapy, } \\
\text { Assistant Dean - Academic Integrity Officer, } \\
\text { Faculty of Health Professions, } \\
\text { Dalhousie University, } \\
\text { Halifax, Nova Scotia }
\end{array}
$$

6. Wee JYM, Hopman WM. Effects of smoke exposure and other lifestyle factors on pain response to electrical stimulation in women. Pain Res Manage 2008;13:231-5.

7. Adams H, Thibault P, Davidson N, Simmonds M, Velly A, Sullivan MJL. Depression augments activity-related pain in women but not in men with chronic musculoskeletal conditions. Pain Res Manage 2008;13:236-42.

8. Evans S, Tsao JCI, Zeltzer LK. Relationship of child perceptions of maternal pain to children's laboratory and nonlaboratory pain. Pain Res Manage 2008;13:211-8.

9. Moon EC, Chambers CT, Larochette A-C, Hayton K, Craig KD, McGrath PJ. Sex differences in parent and child pain ratings during an experimental child pain task. Pain Res Manage 2008;13:225-30. 


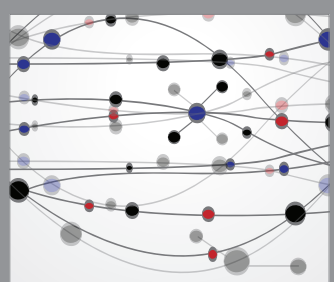

The Scientific World Journal
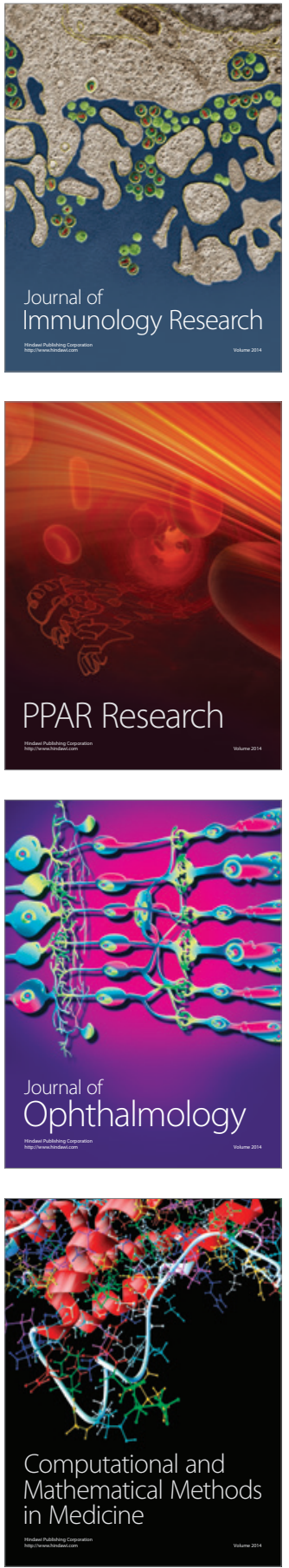

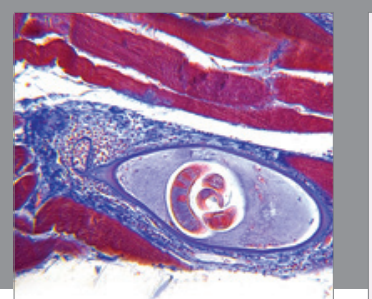

Gastroenterology Research and Practice

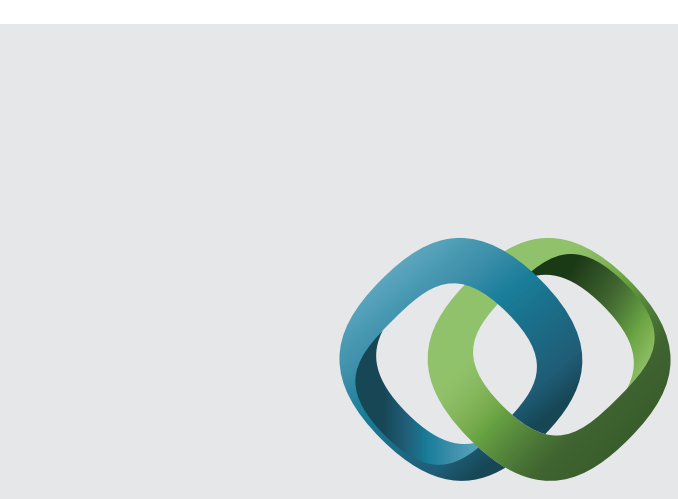

\section{Hindawi}

Submit your manuscripts at

http://www.hindawi.com
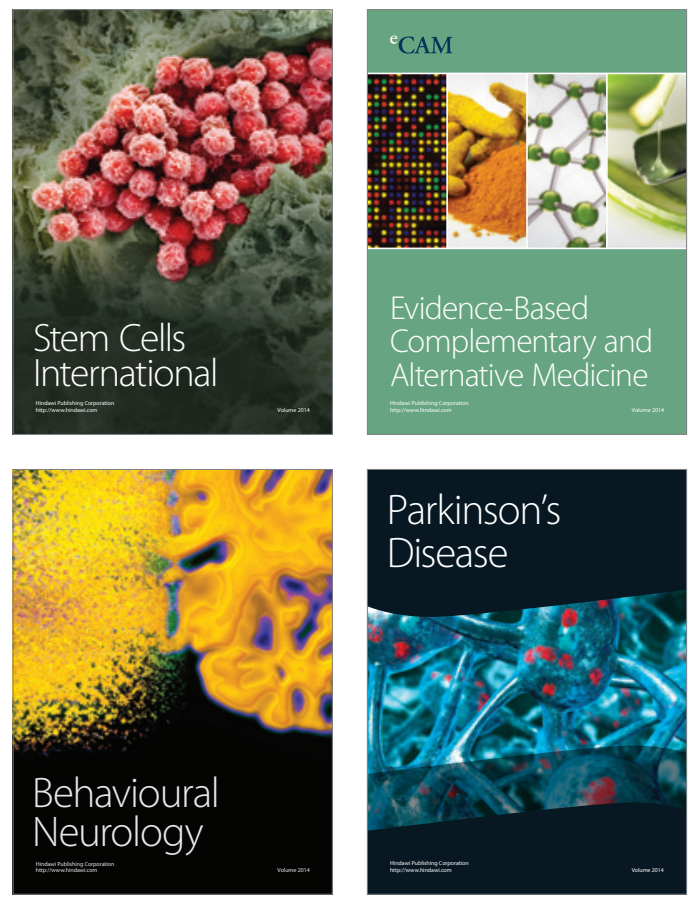


Disease Markers
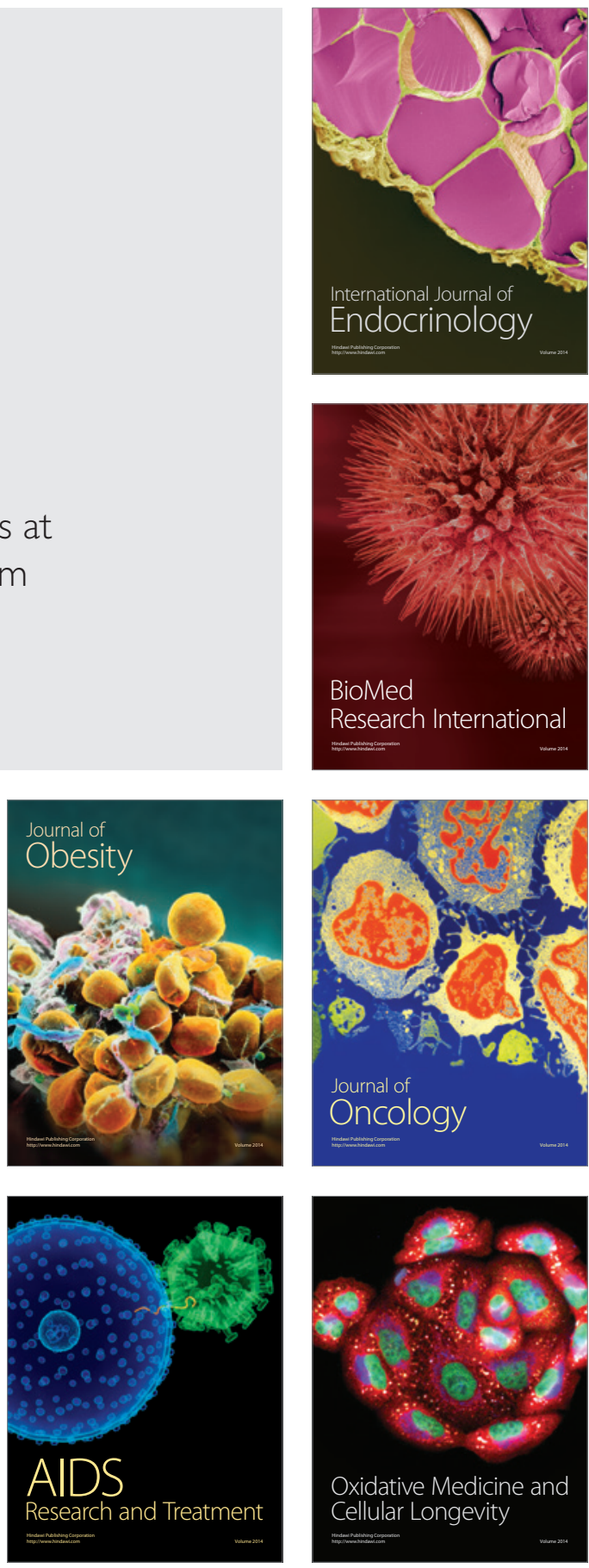